\title{
Ethical dilemmas in choosing a healthful diet: vote with your fork!
}

\author{
Marion Nestle \\ Department of Nutrition and Food Studies, New York University, 35 W 4th Street, 10th Floor, New York, NY 10012-1172, USA
}

\begin{abstract}
Dietary guidelines for health promotion and disease prevention in the USA recommend a consumption pattern based largely on grains, fruit and vegetables, with smaller amounts of meat and dairy foods, and even smaller amounts of foods high in fat and sugar. Such diets are demonstrably health promoting, but following them raises ethical issues related to the role of nutritionists in advising the public about healthful dietary choices, as well as to the role of the food industry in food production and marketing. In the USA a shift towards a more plant-based diet would affect the economic interests of producers of food commodities, food products and meals prepared outside the home; it would also affect the environment, food prices, trade with other countries (developing as well as industrialized) and relationships among the food industry, government agencies (domestic and international) and food and nutrition professionals. In a freemarket economy any dietary choice has consequences for food producers. Thus, considerations of ethical dilemmas in choosing healthful diets suggest that food choices are political acts that offer opportunities for all parties concerned to examine the consequences of such choices and 'vote with forks'.
\end{abstract}

Dietary guidelines: Food choice: Food politics: Food industry

During the twentieth century, within just a few years of recognizing CHD as an epidemic, researchers had identified the dietary correlates of that condition and proposed dietary principles to prevent it, as well as other chronic diseases and their risk factors (Keys \& Keys, 1959). These principles were, and remain, to consume most of the daily energy from fruit, vegetables and grains (plant foods), less from meat and dairy foods (animal foods), and even less from foods high in fat and sugar (James, 1988; US Department of Health and Human Services, 1988). Since 1961 more than 100 governmental and professional committees from thirty-six countries have assessed the implications of research on diet and chronic disease risk, and issued sets of dietary recommendations based on these principles. These recommendations, in effect a worldwide consensus, differ from one another only in minor details (Cannon, 1992).

Beginning in 1980, and every 5 years subsequently, the US Department of Health and Human Services and the US Department of Agriculture (USDA) have jointly issued the US version of such recommendations, the Dietary Guidelines for Americans. By an Act of Congress, the guidelines must be examined every 5 years and, if necessary, revised. The fifth revision appeared in 2000 (US Department of Agriculture and US Department of Health and Human
Services, 2000); it is an official statement of government policy that influences all federal nutrition education, training, assistance and research programmes. To help the public apply the guidelines to daily food choices, USDA issued the food guide pyramid (US Department of Agriculture, 1992). The graphic design of the food guide pyramid is hierarchical and indicates that plant foods constitute the basis of healthful diets, but that foods from other groups should be consumed in lesser amounts (Nestle, 1998). The hierarchies also are illustrated by the recommended number of daily servings from each food group: six to eleven daily from grains, two to four from fruits, three to five from vegetables, and two to three each from the meat and dairy groups. If dietary surveys are to be believed, few Americans follow such recommendations, and typical diets are excessive in energy, sugar and salt, but deficient in intake of dairy foods, vegetables and fruit (Tippett \& Cleveland, 1999).

In 1986, two American nutritionists, Joan Gussow and Kate Clancy, proposed that food choices might regularly be made not merely in terms of their nutritional impact on the individual but in terms of their impact on the long-term stability of the food system (Gussow \& Clancy, 1986). Their analysis demonstrated firm linkages between dietary 
guidelines and issues related to the use and conservation of global soil, water and energy resources. For example, they linked the guideline 'eat a variety of foods' to preservation of biodiversity; consumer demands for variety in food intake ought to promote biological diversity, but the economic demands of the food industry cause supermarkets to be filled with products derived from relatively few raw materials. The promotion of variety to the affluent results in what Gussow (1995) later called a 'seasonless, regionless' diet in which an average food travels $2000 \mathrm{~km}$ before it is eaten, wastes natural resources and causes producers in developing countries to produce food for export rather than for themselves. Although Gussow \& Clancy (1986) did not use the term 'ethics' in their paper, they clearly were delineating ethical dilemmas raised by the implications of dietary guidelines for environmental sustainability, economic power and social justice. In previous work, Clancy (1982) had stated the dilemmas explicitly by questioning whether it is ethical for food companies to market large numbers of resource-intensive high-energy low-nutrient food products to individuals who neither need nor can afford them or, in the case of children, understand the difference between advertising and education.

Such questions assume that following dietary recommendations should improve health and well-being. If ethics is viewed as a matter of inquiry into good and bad conduct (Pepper, 1960), then choosing a healthful diet, and advising individuals to do so, should be considered virtuous actions. It must be stated at the outset that some ethicists question this assumption. HM Malm (unpublished results), for example, in a recent presentation to the American Society of Preventive Oncology, argued that uncertainties in nutrition research and the low probability of diet-related disease in the general population raise what she called 'mass communication risks': misunderstanding and misuse of dietary recommendations; unnecessary fear of harm; undue attention to false as opposed to true health risks. To be ethical, she argues that population-based dietary recommendations, and food-product marketing, must specify the target population likely to benefit, the degree of benefit to be expected, and the risks as well as the benefits. Thus, the very nature of dietary advice raises the dilemma that such advice might do more harm than good, at least to some individuals.

Other dilemmas also arise when dietary advice, or its practice, causes harm to individuals or to society. As Gussow \& Clancy (1986) pointed out, 'virtuous' dietary choices can result in: economic harm to certain food producers; physical harm to the environment; social as well as economic harm to workers in developing countries. Subsequently, USDA economists confirmed the importance of such linkages by estimating what might happen to American agriculture if the US population actually followed dietary recommendations. Their studies revealed that adherence to the guidelines would produce profound dislocations in 'the volume, mix, production, and marketing of agricultural commodities' (O'Brien, 1995), and would require large 'adjustments' in international food trade, non-food uses of basic commodities and food prices (Young $\&$ Kantor, 1999). Some agricultural sectors would benefit if individuals followed dietary guidelines, but others would suffer. What might seem a virtue to some individuals might seem a vice to others: hence, ethical dilemmas.

Although the edition of the dietary guidelines for Americans released in 2000 (US Department of Agriculture and US Department of Health and Human Services, 2000) differs from previous versions in numerous details, it retains their basic principles. Its overall advice to 'aim, build, choose - for good health' places even further emphasis on the benefits of consuming largely plant-based diets, and of reducing the emphasis on animal products and foods high in fat, sugar and salt. Table 1 lists the specific precepts of the guidelines, along with selected ethical dilemmas that might be raised by following them. Using the dietary guidelines as a framework for analysis, the present paper reviews issues related to these dilemmas and describes how their resolution offers individuals an opportunity to make ethical choices by 'voting with their forks'.

\section{Aim for fitness}

\section{Aim for a healthy weight}

The fact that this guideline appears as the first of ten is due to the sharp increase in the prevalence of overweight and obesity among US adults, adolescents and children that has occurred in the past 10-15 years. Overweight results from an imbalance in energy intake and expenditure; although energy expenditure does not appear to have changed much in recent years, energy intake has risen. The average energy intake reported in the USA rose from $7.5 \mathrm{MJ}(1774 \mathrm{kcal}) / \mathrm{d}$ in 1989-91 (Life Sciences Research Office, 1995) to 8.4 MJ (2002 kcal)/d in 1994-6 (US Department of Agriculture, 1997). No matter how imprecise these data, they help explain why more than one-third of US adults are overweight, and why rates of obesity have doubled among children and adolescents since 1989-91 (Troiano et al. 1995; Mokdad et al. 1999) Reversing such trends will require not only changes in individual behavioural patterns, but also the elimination of factors in the environment that impede healthful food choices and active lifestyles (Koplan \& Dietz, 1999; Nestle \& Jacobson, 2000).

Since 1980 US public health policy has included prevention of obesity by individuals and populations as an explicit goal, but implementation plans have focused mainly on individual behaviour change, with calls for federal action limited to a concerted public effort to address the problem (US Department of Health and Human Services, 2000). Only rarely have implementation plans attempted to address the factors in society and the environment that encourage individuals to overeat (Nestle \& Jacobson, 2000). To explain why policies avoid dealing with such factors, it is helpful to understand that the US food supply currently makes available $16 \mathrm{MJ}(3800 \mathrm{kcal}) / \mathrm{d}$ for every man, woman and child in the country, an amount that has increased by $2 \cdot 1 \mathrm{MJ}(500 \mathrm{kcal}) / \mathrm{d}$ since 1970 (Putnam \& Allshouse, 1999). This level is nearly twice the amount needed to meet the energy requirements of most women, one-third more than that needed by most men, and far higher than that needed by infants and young children (National Research Council, 
Table 1. Dietary guidelines for Americans ('aim, build, choose....for good health'; US Department of Agriculture and US Department of Health and Human Services, 2000) and selected ethical dilemmas in applying them to food choices

\begin{tabular}{|c|c|}
\hline Guidelines & Ethical dilemmas \\
\hline \multicolumn{2}{|l|}{ Aim for fitness } \\
\hline \multirow[t]{2}{*}{ Aim for a healthy weight } & Eat less, and cause economic harm to food producers \\
\hline & $\begin{array}{l}\text { Revise government agricultural support, advertising, tax and other population-based policies to } \\
\text { promote 'eat less', and cause economic harm to corporations and individuals } \\
\text { In developing countries establish population-based policies to increase food intake, and } \\
\text { increase the risk of obesity }\end{array}$ \\
\hline Be physically active each day & $\begin{array}{l}\text { Institute taxes and other population-based policies to promote more active lifestyles, and } \\
\text { increase costs to consumers }\end{array}$ \\
\hline \multicolumn{2}{|l|}{ Build a healthy base } \\
\hline Let the food pyramid guide your food choices & $\begin{array}{l}\text { State 'eat less' messages explicitly, and provoke political opposition, or state that there are no } \\
\text { good or bad foods and all foods can be part of healthful diets, and confuse the public } \\
\text { Insist that dietary advice be issued by independent agencies and accept political } \\
\text { consequences, or accept euphemistic recommendations from agencies with conflicting } \\
\text { missions, and confuse the public }\end{array}$ \\
\hline $\begin{array}{l}\text { Eat a variety of grains daily, especially whole } \\
\text { grains }\end{array}$ & $\begin{array}{l}\text { Recommend unprocessed wheat, rice, and oat products low in added fat, sugar and salt, and } \\
\text { risk opposition and higher costs, or advise 'no good foods, no bad foods', and add to public } \\
\text { confusion }\end{array}$ \\
\hline Eat a variety of fruits and vegetables daily & $\begin{array}{l}\text { Insist that produce be grown under conditions that conserve resources, limit pesticides and } \\
\text { herbicides, and support farm workers adequately, and pay more for food }\end{array}$ \\
\hline Keep foods safe to eat & $\begin{array}{l}\text { Require food companies to produce uncontaminated food and test for pathogens, and risk } \\
\text { political opposition and higher costs, or promote safety efforts based on consumer } \\
\text { education, use of irradiation, or other post-market methods, and avoid dealing with root } \\
\text { causes }\end{array}$ \\
\hline \multicolumn{2}{|l|}{ Choose sensibly } \\
\hline $\begin{array}{l}\text { Choose a diet that is low in saturated fat and } \\
\text { cholesterol and moderate in total fat }\end{array}$ & $\begin{array}{l}\text { Require the meat and dairy industries to ensure that their products are free of pathogens and } \\
\text { produced under conditions that do not pollute air, land or water, and incur higher costs }\end{array}$ \\
\hline \multirow[t]{3}{*}{$\begin{array}{l}\text { Choose beverages and foods to moderate } \\
\text { your intake of sugars }\end{array}$} & $\begin{array}{l}\text { Require sugar producers to ensure appropriate standards of environmental and worker } \\
\text { protection, and place jobs at risk }\end{array}$ \\
\hline & $\begin{array}{l}\text { Remove price supports from sugar production, and risk the companies' closing and moving } \\
\text { elsewhere }\end{array}$ \\
\hline & $\begin{array}{l}\text { Regulate marketing of soft drinks and other high-sugar foods to children, especially in school, } \\
\text { and cause economic harm to soft-drink companies and to schools }\end{array}$ \\
\hline Choose and prepare foods with less salt & $\begin{array}{l}\text { Advise population-based salt restriction as a means to prevent hypertension, and } \\
\text { inconvenience individuals who do not need such advice }\end{array}$ \\
\hline $\begin{array}{l}\text { If you drink alcoholic beverages, do so in } \\
\text { moderation }\end{array}$ & $\begin{array}{l}\text { Advise population-based alcohol restriction to reduce social problems and breast-cancer risk, } \\
\text { and eliminate a means of reducing heart-disease risk in certain segments of the population }\end{array}$ \\
\hline
\end{tabular}

1989). Overproduction of energy explains why food companies do everything possible to encourage individuals to eat more of their products. As Joan Gussow (1979) explained more than 20 years ago, "no food company can afford to urge people to eat less of what it produces, however much nutritional sense such advice might make'.

Promotions, pricing, packaging and ubiquity all encourage Americans to eat more food, not less. In 1998, promotion costs for popular confectionery bars were \$10-50 million, for a soft drink \$50-100 million, and for McDonald's more than $\$ 500$ million (Advertising Age, 1999). Such sums vastly exceed any investment of the federal government in weight-control programmes or other kinds of nutrition education programmes. American children are bombarded with dozens of daily television commercials promoting fast foods, snack foods and soft drinks (Kotz \& Story, 1994). Advertisements for such products are commonplace in schools through private television ventures that provide 'news' programmes in exchange for mandatory viewing of commercials by students, and through school-district contracts for exclusive marketing of one or another soft drink in vending machines and sports facilities. Advertising directly targets the food choices of children who now have far more disposable income than they did several decades ago, and far greater influence on their parents' buying habits (McNeal, 1999). US adults spend about half their food budgets on meals and drinks consumed outside the home; such meals tend to be higher in fat and lower in nutrients than those cooked at home (Lin et al. 1999). Servings of restaurant meals and the sizes of food packages in supermarkets have increased significantly since the mid-1980s, and are popular with consumers who appreciate their economic value (Young \& Nestle, 1995).

To counteract such trends, individuals must be encouraged to eat less or to substitute more healthful products, but such advice contradicts food industry imperatives. Despite the high costs of obesity to society (estimated at as much as \$52 billion annually; Wolf \& Colditz, 1998) Congress and state legislatures provide little funding for obesity prevention beyond basic research. Suggestions to tax 'junk' foods or other fiscal measures to fund chronic-disease prevention programmes (Marshall, 2000) are certain to encounter opposition from the affected 
food companies. USDA officials, also, have characterized such proposals as unrealistic and unfriendly to consumers (Kennedy \& Offutt, 2000). Nevertheless, considerable evidence supports the idea that the public would support such taxes if they did not place undue burden on the poor and if they supported health-promotion campaigns (Nestle \& Jacobson, 2000). Beyond concerns about whether it is appropriate to tell anyone what to eat in the name of health, the principal ethical dilemmas underlying anti-obesity campaigns involve the effects of advice to 'eat less' on food producers and the food service industry.

Obesity in developing economies raises somewhat different issues. As economies improve, consumption of meat, sugar and other energy-dense foods increases in conjunction with rapid urbanization and more sedentary lifestyles. Rates of obesity and related chronic diseases rise rapidly and are superimposed on high prevalence rates of infectious diseases and other conditions of undernutrition. In this situation the dilemma is that improving the variety of foods in a diet raises the intake of energy and nutrients, but also places individuals at risk of obesity (Popkin, 1998).

\section{Be physically active}

Based on what can be determined from existing data, the activity levels of Americans appear to have changed little, if at all, from the 1970s to the 1990s (US Department of Health and Human Services, 2000). Influencing adults to increase energy expenditure is a daunting task, because it requires less time spent driving cars, watching television and answering e-mail, and more time spent on more active pursuits (President's Council on Physical Fitness and Sport, 1996). It would also require major intervention into community structures, social patterns and facilities. Neighbourhoods perceived as dangerous discourage individuals from being outdoors, and many suburban neighbourhoods are organized for the convenience of automobile drivers rather than walkers (Centers for Disease Control and Prevention, 1999). Many underfunded school districts have had to eliminate physical education classes in favour of academic courses (another trade-off), and few schools offer other opportunities for students to be physically active.

Government agencies could do more to facilitate more active lifestyles, such as subsidizing bicycle paths, swimming pools and games fields; passing zoning laws that favour pavements and traffic-free areas that encourage individuals to walk to school, work or shopping, and ensuring safety protection for streets, parks and playgrounds. They could also provide greater incentives to use public transport which, in turn, requires individuals to walk to bus stops and train stations. These measures would require higher taxes and would certainly encounter significant opposition not only from politicians, but also from the makers of automobiles, parking garages, television sets, computers and video games who have a vested interest in keeping the population indoors. It is much easier to counsel individuals to be more active than to try to create a physical, social, economic and educational environment that makes energy expenditure pleasant and convenient.

\section{Build a healthy base}

\section{Let the food pyramid guide your food choices}

The food pyramid (US Department of Agriculture, 1992) is the principal nutrition education tool in the USA. As noted earlier, it is meant to help individuals implement the separate precepts of the dietary guidelines (US Department of Agriculture and US Department of Health and Human Services, 2000). Together the guidelines and food pyramid define a distinct dietary pattern based mainly on plant foods. Although the text accompanying this particular guideline makes that idea explicit, the subsequent guidelines listed in Table 1, particularly those suggesting 'eat less', do not. Instead, they undermine this message by expressing advice in terms of nutrients, not foods. They refer to fat, saturated fat and cholesterol, but not to the primary food sources of these nutrients (meat, dairy and fried foods). They refer to salt and sugar, but not to potato chips (crisps) or soft drinks. Indeed, only the 'eat more' precepts (grains and fruits and vegetables) are expressed in food terms. Other terms in the guidelines and food pyramid also require reconstruction, as shown in Table 2.

The confusion inherent in such precepts results directly from the political consequences of dietary advice. Any 'eat less' guideline is certain to be opposed by producers of the affected foods. The history of dietary recommendations in the USA is replete with examples of such opposition (Nestle, 1993a), most recently by the meat industry objecting to the position of its products in the narrower part of the food pyramid (Nestle, 1993b, 1998). Thus, the overriding ethical dilemma associated with dietary guidelines is the conflict between explicit statements of their meaning (eat more plant foods, but eat less meat, dairy and processed foods) and the consequences of such statements for their producers. Gussow (1979) explained: 'These economic realities are a problem worth worrying over. We all need to be concerned - if people start to eat less beef and sugar and Pringles - about the cattle growers, the cane raisers and the Pringle makers ... but we must also recognize that consumers need help choosing foods, and there is no way we can help them select better diets without causing economic disruption to some sectors of the food industry'.

Food industry opposition to 'eat less' messages results directly from the huge amounts of money at stake. The US food industry sold $\$ 890$ billion in foods, beverages and services in 1996, approximately half of it spent on items

Table 2. Dietary advice: clarification of terms

\begin{tabular}{|c|c|}
\hline Term & Translation \\
\hline Grains, vegetables, fruits & Eat a largely plant-based diet \\
\hline $\begin{array}{l}\text { Low in saturated fat, } \\
\text { cholesterol }\end{array}$ & Eat less red meat, fewer dairy foods \\
\hline Variety & $\begin{array}{l}\text { Eat foods low in fat, saturated fat, } \\
\text { cholesterol, sugar and salt }\end{array}$ \\
\hline Choose & Eat less \\
\hline Moderate & Eat less \\
\hline $\begin{array}{l}\text { Two to three servings of } \\
\text { meat per } d\end{array}$ & Eat less red meat \\
\hline $\begin{array}{l}\text { Two to three servings of } \\
\text { dairy per } d\end{array}$ & Eat fewer high-fat dairy products \\
\hline
\end{tabular}


consumed outside the home. The overall growth rate of the industry, however, has been about $1 \%$ annually for many years (Gallo, 1998), a rate far too slow to satisfy executives and shareholders. Thus, food companies resent government suggestions that individuals avoid eating their products. This situation raises a second ethical dilemma; the dual political mandates of the USDA. By directive of Congress this agency is responsible for issuing dietary advice to the public, but its historic mission has been to promote the full range of American agricultural products (regardless of nutritional quality) at home and abroad. The agency cannot be expected to issue unambiguous dietary advice when its primary function is to help industry sell food. Indeed, USDA policies are designed to ensure that food costs remain low; the average American pays approximately $11 \%$ of his (her) income for food, the lowest percentage in the world (Gallo, 1998). Americans expect food to be a low-cost item.

Yet another dilemma affects nutritionists who view the euphemisms used in dietary guidelines as acceptable, and who insist that dietary advice always be stated in positive terms despite ample evidence that the public has difficulty understanding that 'choose' means 'eat less', or 'saturated fat' stands for 'red meat' (Nestle, 1993a). The American Dietetic Association (1996), believing that diets cannot be improved without the support of the food industry, has embraced partnerships and alliances with food companies and a 'total diet' approach to nutrition education: 'there are no good or bad foods; the keys to a good diet are balance, variety, and moderation; and a positive approach to foods should be emphasized'. This approach avoids having to deal with food-group hierarchies and 'eat less' messages, and is far more acceptable to the food industry.

\section{Eat a variety of grains daily, especially whole grains}

Gussow \& Clancy (1986) pointed out that while wholegrain foods (wheat, rice and oats) constitute the basis of healthful diets, the food industry has processed the nutrients and fibre out of these foods and converted them to products high in fat, sugar and salt. These added-value products are of little benefit to the grower and do not promote functional agricultural systems or biodiversity. This dilemma derives from the discrepancy between the 'farm value' of food (the amount that goes to its producer) and the amount that adds value in the form of processing, transportation, marketing and packaging. In 1998, just 20 cents of every $\$ 1$ spent on food went to its producer (Elitzak, 1999). To compete for consumer food purchases, companies want to maximize their share of the remaining 80 cents. Wheat flour is inexpensive, but it is far more profitable when baked and packaged into pretzels and biscuits. Like most processed foods to which fat, sugar and salt have been added, many such products are higher in energy and of lower nutritional quality that the whole grains from which they were derived.

From a business standpoint, it makes sense to add value to basic foods. Thus, economic considerations are the driving force for the creation of new food products. The current food market place includes 240000 packaged foods from US manufacturers alone; an average supermarket offers about 35000 of them at any one time (US Department of Agriculture, 1996). Every year manufacturers introduce large numbers of new food products into the market place; more than 11000 in 1998 (Gallo, 1999). Among these products, three-quarters are confectionery, condiments, breakfast cereals, beverages, bakery products and dairy products, almost all of them from the 'eat less' advice category. Although many of these products fail, many succeed, thereby encouraging the creation of even more.

Competition also stimulates pressures on federal regulatory agencies to permit health claims on product labels and in advertisements. Manufacturers of wheat- and oat-based breakfast cereals, for example, have lobbied successfully for permission to use cholesterol-lowering or cancer-prevention claims; by order of Congress, such claims have proliferated in recent years. Manufacturers have also taken advantage of relaxed health-claim rules for dietary supplements to make so-called structure or function claims for food products, such as 'promotes heart health' or 'supports healthy digestive function'. These claims help sell food products whether or not they can do what is claimed (Geiger, 1998). Following the grain guideline means eating more of unprocessed foods, an action that carries with it a long legacy of health-food faddism (Deutsch, 1977), and also contradicts the dozens of low-carbohydrate highprotein diet plans that have proved so attractive to the weight-conscious public in recent years (Hellmich, 1999). Thus, even though this message is to 'eat more', the wholegrain restriction may not be popular, especially among manufacturers of refined-grain products. Although grain producers should benefit from this advice, the gains will be offset by losses due to declines in production of animal feeds, as discussed later (p. 625).

\section{Eat a variety of fruits and vegetables daily}

Fewer than $3 \%$ of Americans consume three or more servings of vegetables daily, and one of these is usually potatoes (US Department of Health and Human Services, 2000). Gussow \& Clancy (1986) noted some of the potentially negative environmental consequences of promoting this guideline: high energy costs in transporting out-of-season produce, conversion of self-sufficient developing economies to production agriculture, and extensive use of pesticides and energy-intensive fertilizers. As a result of economies of scale, such methods make it possible for produce that has been transported thousands of miles to be sold at prices lower than those charged for locally-grown crops. USDA economists estimate that this 'eat more' guideline would require an additional $4.1 \times 10^{12} \mathrm{~kg} \quad\left(9 \times 10^{12} \mathrm{lb}\right)$ vegetables annually and an additional $0 \cdot 8-1.2 \times 10^{6}$ hectares $\left(2-3 \times 10^{6}\right.$ acres $)$, a shift that would also cause dislocations in agricultural areas. Some of the land planted to fruit and vegetables could compensate for those lost to sugarbeet, maize or soyabean, as discussed later (p. 626), but not easily; shifts in land use are limited by USDA restrictions on crops supported by farm-payment programmes. Most fresh vegetables available in the winter are imported from Mexico, and production would need to increase in that country and others covered by trade agreements. Workers in those countries would get jobs, but at wage and working conditions much 
below those of USA. Such shifts, therefore, would create additional ethical dilemmas related to environmental impact, economic dislocations, labour demands and international trade.

Similar considerations apply to fruit consumption, which would need to double under this guideline (O'Brien, 1995; Young \& Kantor, 1999). Bananas, for example, are the fruit most frequently consumed by Americans; per capita consumption is about seventy-five annually (Sedgewick, 1999). Virtually all this fruit is imported from Central America by the Chiquita company (formerly United Fruit) which has dominated global trade in bananas for a century (Dosal, 1993). When the European Union limited imports of Chiquita bananas in favour of those grown in former colonies, the company used its considerable political influence to induce the US government to file a complaint with the World Trade Organization and to impose high tariffs on European exporters of certain luxury goods (Sanger, 1998). The World Trade Organization supported the USA in this dispute (Kahn, 1999). How the Chiquita company achieved this goal has been described in a riveting account by investigative reporters who 'followed the money' and documented how ' $\$ 5.5$ million in campaign contributions ... bought Chiquita access in Washington' (Bartlett \& Steele, 2000). The reporters noted that the government's decision to pursue a trade war over bananas differed from its handling of issues related to other agricultural products, and was especially noteworthy because Chiquita already controlled $20 \%$ of the European banana market, even with trade restrictions. Other reporters explain this anomaly as an attempt to strengthen the ability of the World Trade Organization to negotiate international trade disputes (Weinstein, 1998) or as an effort to shore up the Chiquita company's flagging stock prices (Cotts, $1999 a)$.

The most bizarre ethical consequence of the banana wars involved freedom of the press (Stein, 1998). In May 1998 the Cincinnati Enquirer published a lengthy account of a 1-year-long investigation of Chiquita's 'unsavoury' practices in banana-producing countries: creation of secret companies to avoid local land and labour laws; bribery of local officials; irresponsible use of pesticides that harmed workers and the environment; harsh treatment of plantation residents (Gallagher \& McWhirter, 1998). As the reporters had used illegally obtained recordings of voice-mail messages as a source, the company sued the newspaper and forced it to publish an apology, fire the reporters and pay a $\$ 10$ million settlement fee (Cincinnati Enquirer, 1998). The company also sued one of the reporters for defamation. Later accounts revealed that the judge who assigned himself to the defamation case had received campaign contributions from Chiquita executives as well as from the special prosecutor who was investigating the charges (Associated Press, 1998). To the distress of commentators concerned about journalistic ethics, the principal reporter revealed his source as part of a plea bargain (Frantz, 1999). This drama served to detract from the content of the investigative report itself. Although the company denied the accusations, neither it nor anyone else produced evidence to suggest that they were false (Cotts, 1999b).

\section{Keep foods safe to eat}

Demands for inexpensive meats and year-round produce have increased the prevalence of food-borne illnesses. Microbial contaminants are ubiquitous in raw foods, but rarely cause problems in foods that have been cooked and stored properly. The principal food-borne illnesses begin with pathogenic bacteria, protozoa or viruses that infect animals, often without making them sick. The animals excrete the pathogens in faeces, which come into contact with meat or crops through water or handling. The increasing concentration of food production as well as other changes in food distribution have favoured the emergence of increasingly harmful pathogens in food, their resistance to common preservation methods and to antibiotics, and their spread to increasingly large groups of the population.

As discussed later (p. 625), food animals are increasingly raised in fewer, but much larger, units. In the US today, for example, just $3 \%$ of the pig farms produce $50 \%$ of total pig output, and $2 \%$ of feedlot operations account for $40 \%$ of the cattle output (Center for Public Integrity, 1998). This situation leads to vast 'lagoons' of manure, and consequent pollution of air, land and water. The use of raw manure to fertilize fields and orchards brings pathogenic bacteria into contact with grains, vegetables and fruits not normally contaminated with harmful organisms. Food-borne microorganisms are believed to cause a minimum of $14 \times 10^{6}$ episodes of illness, 61000 hospitalizations and 1800 deaths in the USA (Mead et al. 1999) at an annual cost of \$37 billion in health care and lost productivity (General Accounting Office, 1998). The intense concentration of animal production has also increased the use of antibiotics. Low-dose antibiotic drugs have been used routinely as growth promoters, a practice long known to encourage growth of resistant strains that can be passed from animals to human subjects (Holmberg et al. 1984). As the dangers of antibiotic-resistant food-borne contaminants have become more evident, and the types of resistant bacteria and the range of antibiotics they resist have increased, calls for corrective action have become more urgent (Levy, 1998).

Food safety should be a matter of preventing animal infections (by producers), avoiding faecal contamination (by processors), and destroying any remaining harmful microbes (by consumers), but producers and processors typically blame one another for failing to protect the public, and both blame consumers for not cooking foods properly. It is easier for government to focus safety efforts on consumer education than to attempt to impose regulations on the powerful meat industry and drug companies (Leonard, 1998).

Food safety is also linked to much broader societal concerns. Since much of the work in agriculture, processing plants and food service establishments is carried out by immigrants and other groups paid minimum wages without health-care or sick-leave benefits, the production of safe food also depends on the adequacy of public education, health care and social support systems. Much winter produce is imported from countries in Asia, Latin America, Indonesia and North Africa, where water quality, sanitation and working conditions do not necessarily meet US standards (General Accounting Office, 1998). Eating 
restaurant and other pre-prepared foods means that they are handled more between harvest and consumption, increasing the chance of passing along a food-borne illness. Thus, prevention of food contamination is closely linked to the need to educate individuals, pay them decently and provide adequate sick-leave and health-care benefits, all of which would greatly increase the cost of food, thereby making it more difficult for the poor to meet nutritional needs.

\section{Choose sensibly}

\section{Choose a diet that is low in saturated fat and cholesterol and moderate in total fat}

This guideline is a euphemism for 'eat less'; in this case, of beef (which is the major source of saturated fat in the USA), animal fat and processed foods high in fat. The guideline addresses the ultimate ethical dilemma: to eat meat at all is to cause harm to animals. To follow this guideline, individuals must either eat less meat or substitute fish, chicken and lean beef or pork for high-fat meats. Gussow (1995) has discussed the ecological constraints on increased fish production; oceans have already reached their maximum productivity and the quality of available fish has declined markedly. The deleterious impact of fish farming on the environment has become an issue of great concern (Goldburg \& Triplett, 1997). The increasing demand for lean pork and chicken has contributed to a dramatic concentration of animal production in the USA, with shocking environmental consequences. Just 30 years ago many thousands of small farmers raised chickens that were supplied and processed by numerous feed mills and local operations throughout the fifty states. Today, just a few gigantic corporations control every aspect of chicken production from egg to retail outlet, and virtually no independent producers remain (Silverstein, 1999). Since the late 1980s, the number of pig farms has declined by two-thirds, but the number of pigs raised on the remaining farms has tripled (General Accounting Office, 1999a). Just from 1997 to 1998 the number of pig operations fell from 122000 to 114000 , while the number of animals rose from sixty-one million to sixty-two million (National Agricultural Statistics Service, 1999). From 1988 to 1998 the average number of pigs per farm increased from 172 to 544, and the proportion of farms marketing more than 50000 pigs annually increased from $7 \%$ to $37 \%$ (General Accounting Office, 1999a). Although concentration has produced great wealth for the corporations, employees in the industry are poorly paid and their working conditions are considered dangerous and 'grim' (Silverstein, 1999). By the late 1990s pigs were so overproduced that farmers could not recover their costs (Barboza, 1998; General Accounting Office, 1999a).

Factory production of pigs and chickens places hundreds of thousands of animals and birds in close quarters, a situation that fosters rapid transmission of microbial pathogens and promotes use of antibiotics. It is also easy to understand why disposal of manure from such factories might be a problem. When farms raise just a few animals they can compost manure, a process that generates enough heat to kill most bacteria. With large numbers of animals, however, there is too much manure for the land to absorb, and any breach in the waste 'lagoons' irreparably pollutes streams and groundwater (Kilborn, 1999). Large pig operations, for example, are believed to be responsible for the degradation of $22000 \mathrm{~km}$ (35000 miles) of waterways in twenty-two states (Johnson, 1999) and animal waste in general to be responsible for $60 \%$ of the polluted rivers and streams in the USA (Silverstein, 1999). Poultry waste is responsible for creating conditions leading to contamination of fish in Chesapeake Bay with Pfiesteria piscicida, and to levels of nitrate in local drinking water that greatly exceed federal clean-water standards (Goodman, 1999). As a result of close financial connections between meat and poultry corporations and Congressional Agriculture Committees, production and disposal of animal wastes remain largely unregulated. When faced with regulation the corporations threaten to move their operations to remote areas of Canada or to Mexico where rules and labour costs are less onerous (Johnson, 1999).

USDA economists worry about the effects on agricultural producers of following dietary guidelines, particularly because more than one-third of cereal-grain production is fed to animals. If demand for lean meats increased, retail prices would rise, and higher-fat products would shift to pet foods and industrial uses, or would be shipped to export markets. A reduction in overall fat intake would result in a $36 \%$ decline in demand for soyabean and a loss of $4.9 \times 10^{6}$ hectares $\left(12 \times 10^{6}\right.$ acres $)$ devoted to soyabean production, primarily in midwestern states. Adverse effects on the local economies of countries exporting tropical oils to the USA could also be expected (Young \& Kantor, 1999). As O'Brien (1995) explained, 'the agricultural sector has the physical capacity to support healthier diets, but ... doing so might involve difficult tradeoffs'. Increasing demands for meat in developing economies will surely generate similar dilemmas.

\section{Choose beverages and foods to moderate your intake of sugars}

The principal sources of added sugars in US diets are soft drinks, confectionery, bakery products (cakes, biscuits etc.), fruit drinks and dairy desserts (all high-energy foods of

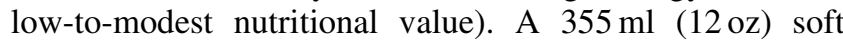
drink, for example, provides about $628 \mathrm{~kJ}(150 \mathrm{kcal})$, all from sugars, but no other nutrients of significance (Putnam \& Allshouse, 1999). Researchers have demonstrated that children who consume soft drinks take in more daily energy and are more obese than those who do not (Harnack et al. 1999). This guideline clearly means 'eat less'. To do so, however, means confronting overwhelming marketing efforts. Despite its recent difficulties in Europe and other parts of the world (Hays, 2000), Coca-Cola is an international symbol of American marketing genius, and the company's stated strategy is to make its products readily available to everyone, everywhere. The domestic advertising budget for Classic Coke alone was $\$ 115 \cdot 5$ million in 1998 (Advertising Age, 1999). To further stimulate sales the company has increased the size of its bottles. In the 1950s Coca-Cola was sold only in $190 \mathrm{ml}$ $(6.5 \mathrm{oz})$ bottles. Later, the company expanded single 
servings to $355 \mathrm{ml}(12 \mathrm{oz})$ cans, and more recently to $590 \mathrm{ml}$ $(20 \mathrm{oz})$ bottles. As soft-drink marketing has become more competitive, companies have focused efforts on attracting younger and younger children as customers, particularly through school advertising and exclusive contracts with school districts (Jacobson, 1998). The companies defend such practices on the grounds that they are providing resources needed by schools, and teaching children valuable lessons about the workings of market economies (Smith, 1997). In this situation, consuming fewer soft drinks would not only cause economic harm to their manufacturers, but would also remove a funding source important to many schools.

USDA economists estimate that following this guideline would lead to a $60 \%$ reduction in the consumption of energy-containing sweeteners which, in turn, would translate into an annual reduction of $4.9 \times 10^{6} \mathrm{t}\left(4.8 \times 10^{6}\right.$ tons). This reduction would also cause a loss of $0.28 \times 10^{6}$ hectares $\left(0.7 \times 10^{6}\right.$ acres $)$ planted to sugarcane and $0.45 \times 10^{6}$ hectares $\left(1.1 \times 10^{6}\right.$ acres) to sugarbeet (Young \& Kantor, 1999). Sugarcane production is concentrated in two Southern states, Florida and Louisiana, where canefields employ migrant labour from Caribbean countries under conditions that raise human-rights concerns (Wilkinson, 1989). Such jobs, however, would be lost if the cane fields were reduced in size. Florida sugar production is believed to be responsible for blocking the free flow of water into the Everglades, causing erosion and contamination. Reduced demand might help this situation, but the large sugar companies have successfully resisted any attempt to save the Everglades by returning the cane fields to marshland. Owners of Florida sugar plantations contribute large sums to both political parties and have unusual access to the highest levels of government (McKinley, 1999). A decline in sugar intake would also affect maize production, since maize syrups account for more than half the total energycontaining sweetener consumption (Putnam \& Allshouse, 1999); the area under production would fall by about $1.42 \times 10^{6}$ hectares $\left(3.5 \times 10^{6}\right.$ acres $)$, and losses would also adversely affect the wet-mill companies that process maize into syrups for use in soft drinks and other purposes (Young \& Kantor, 1999).

Discussions of domestic sugar and sweetener production are complicated by the elaborate system of price supports and import restrictions that protect this industry and keep US prices well above those of world markets. In the early 1990s the increased prices cost American consumers \$1.4 billion annually, to the benefit of large sugar growers and manufacturers of maize syrups; an estimated $42 \%$ of such benefits went to just $1 \%$ of the sugar farms. Foreign countries that export sugar to the USA also benefit from the higher prices, as certain favoured countries may export negotiated amounts at no or low duty (General Accounting Office, 1995). Before the Castro revolution, nearly all imported sugar was purchased from Cuba, and the USA bought more than half the Cuban sugar production (Pérez-López, 1991). Today, the USA grants sugar-import quotas to forty countries, principally the Dominican Republic, Brazil, the Philippines and Australia (General Accounting Office, 1999b). USDA economists estimate that imported sugar would decline by two-thirds if this guideline were followed, thereby affecting the economies of the quota countries.

\section{Choose and prepare foods with less salt}

Current scientific debates about the relationship of salt to high blood pressure are astonishing in their ferocity (MacGregor \& de Wardener, 1998; Taubes, 1998), but committees continue to view the preponderance of evidence as favouring salt restrictions as a public health measure (US Department of Agriculture and US Department of Health and Human Services, 2000). Since most salt in American diets derives from processed and pre-prepared foods, this 'eat less' guideline means fewer packaged foods and fast foods. The addition of salt to processed foods masks taste changes that occur in processing and encourages greater consumption of energy-rich snacks. Lobbying groups such as the Salt Institute (Washington, DC, USA), however, systematically issue news bulletins and press releases promoting information (scientific and otherwise) that might appear to weaken any association between salt intake and disease. Following this guideline conflicts with the economic interests of the salt and processed-food industries.

\section{If you drink alcoholic beverages, do so in moderation}

This guideline means 'drink less' (if you drink at all). In the USA sales of alcoholic beverages have been declining for at least 20 years, as individuals have replaced spirits with beer, wine and soft drinks (Putnam \& Allshouse, 1999). As a result of the substantial evidence that links moderate alcohol consumption with reduced risk of CHD, lobbying groups for the wine industry are using this guideline to promote increased consumption of their products and to argue that federal guidelines should suggest that everyone drinks a little alcohol (preferably wine) each day (Nestle, 1997). These efforts are especially questionable in the light of the substantial social problems caused by excessive drinking, and by evidence that even low alcohol consumption may increase the risk of breast cancer (Smith-Warner et al. 1998). In this case the benefits of moderate drinking for some groups must be balanced against the harm caused to others by promoting any increase in alcohol consumption.

\section{Vote with your fork!}

This discussion should make it evident that following dietary recommendations has economic, political, social and environmental consequences. These consequences place improvements to the health of individuals or populations in conflict with other considerations and, therefore, raise ethical issues. Table 3 summarizes some of the ethical questions suggested by food-production and marketing practices, and nutritionists' responses to them. In following dietary guidelines, gains in nutritional status must be balanced against potentially higher food prices, damage to the environment, pressures on natural resources, increased safety risks to workers and consumers, inadequate support of farm labour in developing countries and large-scale 'dislocations' in the feed-livestock complex (O'Brien, 1995). Agricultural economists consider the necessary 
Table 3. Ethical questions in food choice

Production methods
Do they respect animal 'rights'?
Do they protect and preserve natural resources?
Do they avoid pollution of air, land and water?
Do they adequately reward producers of basic farm commodities?
Do they ensure food safety?
Do they ensure worker safety?
Do they provide adequate wages, living conditions and education
for workers and their children?
Do they promote nutritional quality?
Marketing methods
Do they avoid inappropriate targeting of children?
Do they emphasize products of high nutritional quality?
Do they disclose the contents of products?
Do they disclose processing methods such as irradiation or
genetic engineering?
Do they avoid making inappropriate or misleading health claims?
Do they avoid inappropriate pressures on officials in legislative,
judiciary and executive branches of government?
Do they avoid inappropriate pressures on journalists or their
employers?
Do they avoid involving nutrition and food professionals in conflicts
of interest?
Counselling methods
Do they consider the balance between risks and benefits
whenever possible?
Do they take ethical issues into consideration?
Do they promote ethical choices whenever possible?

changes to be so expensive or disruptive that they will create impossible political barriers. Rather than instituting major national efforts to encourage more healthful eating patterns, they suggest that the food supply be improved through biotechnology, nutrient fortification and development of 'functional' foods with added nutritional value (O'Brien, 1995; Kennedy \& Offutt, 2000). Such proposals, however, raise ethical dilemmas of their own (Gussow \& Akabas, 1993; Silverglade \& Jacobson, 1999).

It should be evident from the present discussion that the ethical options available to consumers and nutritionists in the current global food system are somewhat limited. Governments make choices for their populations in the name of free-market economies, and corporations do whatever they can to induce individuals to buy more of their products. Gussow \& Clancy (1986) have proposed an alternative: to choose foods not only for reasons of health, but also for reasons related to how and where they are produced. They argue that buying locally-produced organically-grown food would not only improve the nutritional quality of the diet, but would also support local farmers, promote functioning communities, and help to create an alternative to industrial agriculture. In the early 1990s Oldways Preservation \& Exchange Trust (a Boston (MA, USA)-based group devoted to incorporating traditional foodways into current dietary choices) recognized the political consequences of food choice in urging chefs and restaurateurs to 'vote with your fork!' and forge alliances with local food producers. The value of such alliances is illustrated by the purchasing practices of a small (sixty-five-seat) vegan restaurant, Angelica's Kitchen, in New York City (NY, USA). The restaurant buys $907 \mathrm{~kg}$ $(2000 \mathrm{lb})$ red cabbage, $1134 \mathrm{~kg}(2500 \mathrm{lb})$ greens (mustard, collards, kale), $1360 \mathrm{~kg}(3000 \mathrm{lb})$ onions and $2268 \mathrm{~kg}$ $(5000 \mathrm{lb})$ carrots each month, all of it organically grown and much of it from local suppliers (McEachern, 2000).

Choosing to support such alliances is one way to resolve ethical dilemmas, but the higher costs and inconvenience of doing so is certain to preclude such choices for many (if not most) of the population. Unless we are willing to pay more for food, and to relinquish out-of-season produce, we support the current food system every time we eat a meal. Thus, voting with forks must extend beyond the food choices of individuals to larger political arenas. The current food system is supported directly or indirectly by numerous government policies and regulations (Ralston, 1999) that could well be revised to promote more healthful diets rather than the economic interests of the food industry. Doing so will always involve trade-offs that benefit some groups at the expense of others. Such trade-offs offer an opportunity to consider ethical implications whenever we make healthful food choices or advise the public to do so.

\section{Acknowledgements}

The author thanks Joan Gussow and Kate Clancy for inspiration and permission to adapt their method of analysis, Ralph Early for explaining how the main schools of ethical thought might approach considerations of food choice, Oldways Preservation \& Exchange Trust for permission to use their slogan, 'Vote With Your Fork!', in this context, Professors Alan Hausman and Amy Bentley for comments on an early draft of this article, and Stacey Freis for research assistance. This work was supported by research challenge grants from New York University and its School of Education.

\section{References}

Advertising Age (1999) 44 ${ }^{\text {th }}$ Annual: 100 leading national advertisers. Advertising Age 27 September issue, s1-s46.

American Dietetic Association (1996) Position of the American Dietetic Association: nutrition education for the public. Journal of the American Dietetic Association 96, 1183-1187.

Associated Press (1998) Judge got contributions from Chiquita execs, special prosecutor. Cincinnati Enquirer 10 July issue. http://enquirer.com/editions/1998/07/10

Barboza D (1998) Farmers are in crisis as hog prices collapse. The New York Times 13 December issue, 29.

Bartlett DL \& Steele JB (2000) How to become a top banana. Time 7 February issue, 42-56.

Cannon G (1992) Food and Health: the Experts Agree. London: Consumers' Association.

Center for Public Integrity (1998) Safety Last: The Politics of E. coli and Other Food-borne Killers. Washington, DC: Center for Public Integrity.

Centers for Disease Control and Prevention (1999) Neighborhood safety and the prevalence of physical inactivity - selected states, 1996. Morbidity and Mortality Weekly Report 48, 143-146.

Cincinnati Enquirer (1998) An apology to Chiquita. Cincinnati Enquirer 28 June issue, A1.

Clancy KL (1982) Ethical issues in food processing and marketing, or a nutritionist talks about 'moral fiber'. Agriculture, Change 
and Human Values. Proceedings of a Multidisciplinary Conference, October 18-21. Gainesville, FL: University of Florida.

Cotts C (1999a) Banana flackery. The Village Voice 5 January issue, 26.

Cotts C (1999b) Bananarama. The Village Voice 4 May issue, 32.

Deutsch RM (1977) The New Nuts Among the Berries. How Nutrition Nonsense Captured America. Palo Alto, CA: Bull Publishing.

Dosal PJ (1993) Doing Business with the Dictators: A Political History of United Fruit in Guatamala, 1899-1944. Wilmington, DE: Scholarly Resources, Inc.

Elitzak H (1999) Desire for convenience drives marketing costs. FoodReview 22, 23-25.

Frantz D (1999) Word of honor: for a reporter and a source, echoes of a broken promise. The New York Times 11 April issue, D3.

Gallagher M \& McWhirter C (1998) Chiquita secrets revealed: hidden control crucial to overseas empire. Cincinnati Enquirer 3 May issue, C1-C18.

Gallo AE (1998) The Food Marketing System in 1996. Agriculture Information Bulletin no. 743. Washington, DC: US Department of Agriculture.

Gallo AE (1999) Fewer food products introduced in last 3 years. FoodReview 22, 27-29.

Geiger CJ (1998) Health claims: history, current regulatory status and consumer research. Journal of the American Dietetic Association 98, 1312-1322.

General Accounting Office (1995) Sugar Program: Impact on Sweetener Users and Producers. GAO/T-RCED-95-204. Washington, DC: US General Accounting Office.

General Accounting Office (1998) Food Safety: Federal Efforts to Ensure the Safety of Imported Foods are Inconsistent and Unreliable. GAO/RCED-98-103. Washington, DC: US General Accounting Office

General Accounting Office (1999a) Pork Industry: USDA's Reported Prices Have Not Reflected Actual Sales. GAO/RCED-00-26. Washington, DC: US General Accounting Office.

General Accounting Office (1999b) Sugar Program: Changing the Method for Setting Import Quotas Could Reduce Costs to Users. GAO/RCED-99-209. Washington, DC: US General Accounting Office.

Goldburg R \& Triplett T (1997) Murky Waters: Environmental Effects of Aquaculture in the United States. New York: Environmental Defense Fund.

Goodman PS (1999) Poultry's price: the cost to the Bay. An unsavory byproduct: runoff and pollution. The Washington Post 1 August issue, A1.

Gussow JD (1979) Can industry afford a healthy America? CNI Weekly Report 7 June issue, 4-7.

Gussow JD (1995) Mediterranean diets: are they environmentally responsible? American Journal of Clinical Nutrition 61, Suppl., $1383 \mathrm{~s}-1389 \mathrm{~s}$.

Gussow JD \& Akabas S (1993) Are we fixing up the food supply? Journal of the American Dietetic Association 93, 1300-1304.

Gussow JD \& Clancy K (1986) Dietary guidelines for sustainability. Journal of Nutrition Education 18, 1-5.

Harnack L, Stang J \& Story M (1999) Soft drink consumption among US children and adolescents: nutritional consequences. Journal of the American Dietetic Association 99, 436-441.

Hays CL (2000) Learning to think smaller at Coke. The New York Times 6 February issue, C1,C5.

Hellmich N (1999) High-protein diets gaining support. USA Today Health 21 September issue. http://www.usatoday.com/

Holmberg SD, Osterholm MT, Senger KA \& Cohen ML (1984) Drug-resistant Salmonella from animals fed antimicrobials. New England Journal of Medicine 311, 617-622.
Jacobson MF (1998) Liquid Candy: How Soft Drinks are Harming Americans' Health. Washington, DC: Center for Science in the Public Interest.

James WPT (1988) Health Nutrition: Preventing Nutrition-Related Diseases in Europe. Copenhagen, Denmark: WHO Regional Office for Europe.

Johnson D (1999) Pork producer settles suit as pollution rules tighten. The New York Times 16 August issue, A12.

Kahn J (1999) U.S. wins round in trade war with Europe. The New York Times 23 December issue, C2.

Kennedy E \& Offutt S (2000) Commentary: alternative nutrition outcomes using a fiscal food policy. British Medical Journal 320, 304-305.

Keys A \& Keys M (1959) Eat Well and Stay Well. New York: Doubleday \& Co.

Kilborn PT (1999) Hurricane reveals flaws in farm law as animal waste threatens N. Carolina water. The New York Times 17 October issue, 32.

Koplan JP \& Dietz WH (1999) Caloric imbalance and public health policy. Journal of the American Medical Association 282, $1579-1580$.

Kotz K \& Story M (1994) Food advertisements during children's Saturday morning television programming: are they consistent with dietary recommendations? Journal of the American Dietetic Association 94, 1296-1300.

Leonard R (1998) Drugs as feed additives increase risk to health. Nutrition Week 7 August issue, 4-5.

Levy SB (1998) Private arsenals and public peril. New England Journal of Medicine 338, 1375-1378.

Life Sciences Research Office (1995) Third Report on Nutrition Monitoring in the United States, vol. 2, Washington, DC; Government Printing Office.

Lin B-H, Frazão E \& Guthrie J (1999) Away-from-Home Foods Increasingly Important to Quality of American Diet. Agricultural Information Bulletin no. 749. Washington, DC: US Department of Agriculture.

McEachern L (2000) The Angelica Home Kitchen. New York: Arcade Press.

MacGregor GA \& de Wardener HE (1998) Salt, Diet \& Health. Cambridge: Cambridge University Press.

McKinley JC (1999) Sugar industry's pivotal role in Everglades effort. The New York Times 16 April issue, A19.

McNeal JU (1999) The Kids Market: Myths and Realities. Ithaca, NY: Paramount Market Publishing.

Marshall T (2000) Exploring a fiscal food policy: the case of diet and ischaemic heart disease. British Medical Journal 320 301-304.

Mead PS, Slutsker L, Dietz V, McCaig LF, Bresee JS, Shapiro C, Griffin PM \& Tauxe RV (1999) Food-related illness and death in the United States. Emerging Infectious Diseases 5. http://www.cdc.gov/ncidod/eid/vol5no5/mead.htm

Mokdad AH, Serdula MK, Dietz WH, Bowman BA, Marks JS \& Koplan JP (1999) The spread of the obesity epidemic in the United States, 1991-1998. Journal of the American Medical Association 282, 1519-1522.

National Agricultural Statistics Service (1999) Agricultural Statistics 1999, sect. VII, p 19. Washington, DC: Government Printing Office.

National Research Council (1989) Recommended Dietary Allowances, 10th ed. Washington, DC: National Academy Press.

Nestle M (1993a) Food lobbies, the food pyramid, and US nutrition policy. International Journal of Health Services 23, 483-496.

Nestle M (1993b) Dietary advice for the 1990s: the political history of the food guide pyramid. Caduceus 9, 136-153.

Nestle M (1997) Alcohol guidelines for chronic disease prevention: from prohibition to moderation. Nutrition Today 32, 86-92. 
Nestle M (1998) In defense of the USDA Food Guide Pyramid. Nutrition Today 33, 189-197.

Nestle M \& Jacobson MF (2000) Halting the obesity epidemic: A public health policy approach. Public Health Reports 115, 12-24.

O'Brien P (1995) Dietary shifts and implications for US agriculture. American Journal of Clinical Nutrition 61, Suppl., 1390s-1396s.

Pepper SC (1960) Ethics. New York: Appleton-Century-Crofts.

Pérez-López JF (1991) The Economics of Cuban Sugar. Pittsburgh, PA: University of Pittsburgh Press.

Popkin BM (1998) The nutrition transition and its health implications in lower-income countries. Public Health Nutrition 1, 5-21.

President's Council on Physical Fitness and Sports (1996) Physical Activity and Health: A Report of the Surgeon General. Washington, DC: US Department of Health and Human Services.

Putnam JJ \& Allshouse JE (1999) Food Consumption, Prices, and Expenditures, 1970-97. Statistical Bulletin no. 965. Washington, DC: US Department of Agriculture.

Ralston K (1999) How government policies and regulations can affect dietary choices. In America's Eating Habits: Changes \& Consequences. Agricultural Information Bulletin no. 750, pp. 331-370 [E Frazão, editor]. Washington, DC: US Department of Agriculture.

Sedgewick SW (1999) Yes! We have nice bananas. The Washington Post 3 February issue, F1, F2.

Sanger DE (1998) U.S.-Europe trade war looms over bananas. The New York Times 22 December issue, A1, C5.

Silverglade B \& Jacobson MF (editors) (1999) Functional Foods Public Health Boon or $21^{\text {st }}$ Century Quackery? Washington, DC: Center for Science in the Public Interest.

Silverstein K (1999) Meat factories. Sierra January and February issue, 28-35, 110-112.

Smith G (editor) (1997) Children's Food: Marketing and Innovation. London: Blackie Academic \& Professional.

Smith-Warner SA, Spiegelman D, Yaun S-S, van den Brandt PA, Folsom AR, Goldbohm RA, Graham S, Holmberg L, Howe GR, Marshall JR, Miller AB, Potter JD, Speizer FE, Willett WC, Wolk A \& Hunter DJ (1998) Alcohol and breast cancer in women: a pooled analysis of cohort studies. Journal of the American Medical Association 279, 535-540.

Stein N (1998) Banana peel. Columbia Journalism Review September October issue, 46-51.

Taubes G (1998) The (political) science of salt. Science 281, 898-907.
Tippett KS \& Cleveland LE (1999) How current diets stack up: comparison with dietary guidelines. In America's Eating Habits: Changes \& Consequences, Agricultural Information Bulletin no. 750, pp. 51-70 [E. Frazão, editor]. Washington, DC: US Department of Agriculture.

Troiano RP, Flegal KM, Kuczmarski RJ, Campbell SM \& Johnson CL (1995) Overweight prevalence and trends for children and adolescents. The National Health and Nutrition Examination Surveys, 1963 to 1991. Archives of Pediatric and Adolescent Medicine 149, 1085-1091.

US Department of Agriculture (1992) The Food Guide Pyramid. Home and Garden Bulletin no. 252. Washington, DC: Government Printing Office.

US Department of Agriculture (1996) Food Marketing Review, 1994-95. Agricultural Economic Report no. 743. Washington, DC: US Department of Agriculture.

US Department of Agriculture (1997) Data tables: Results from USDA's 1994-96 continuing survey of food intakes by individuals and 1994-96 diet and health knowledge survey. http://www.barc.usda.gov/bhnrc/foodsurvey/home.htm Accessed 23 February 1999.

US Department of Agriculture and US Department of Health and Human Services (2000) Dietary Guidelines for Americans, 5th ed. Home and Garden Bulletin no. 232. Washington, DC: Government Printing Office.

US Department of Health and Human Services (1988) The Surgeon General's Report on Nutrition and Health. DHHS (PHS) Publication no. 88-50210. Washington, DC: Government Printing Office.

US Department of Health and Human Services (2000) Healthy People 2010: Understanding and Improving Health. Conference ed. Washington, DC: Government Printing Office.

Weinstein MM (1998) The banana war between the United States and Europe is more than a trivial trade spat. The New York Times 24 December issue, C2.

Wilkinson A (1989) Big Sugar: Seasons in the Cane Fields of Florida. New York: Knopf.

Wolf AM \& Colditz GA (1998) Current estimates of the economic cost of obesity in the United States. Obesity Research 6, 97-106.

Young CE \& Kantor LS (1999) Moving Toward the Food Guide Pyramid: Implications for US Agriculture. Agricultural Economic Report no. 779. Washington, DC: US Department of Agriculture.

Young LR \& Nestle M (1995) Portion sizes in dietary assessment: issues and policy implications. Nutrition Reviews 53, 149-158. 